\title{
Online vs Konvensional: Keunggulan dan Konflik Antar Moda Transportasi di Kota Makassar
}

\author{
Ahsani Amalia Anwar
}

Lokus Research and Consulting (LRC). Email: ahsaniamaliaanwar@gmail.com

\begin{tabular}{l}
\hline ARTICLE INFO \\
\hline Keywords: \\
Transportation; \\
konventional; application; \\
online; drivers; consumer; \\
conflict. \\
How to cite: \\
Anwar, Ahsani Amalia. \\
(2017). Online vs \\
Konvensional: \\
Eksistensi dan Konflik \\
Antar Moda Transportasi \\
di Kota Makassar. Etnosia: \\
Jurnal Etnografi \\
Indonesia, 2(2), 220-246. \\
\end{tabular}

\begin{abstract}
The existence of online mode of transportation has attracted consumers' attention, and therefore many switch from the use of conventional to online mode of transportation. The switch has become a trigger of conflict between drivers of conventional transportation, such as city transportation (angkot), taxi, motorbike (bentor), rickshaw (ojek pangkalan), and drivers of online transportation, such as Grab and Go-Jek. This artikel is focused on the existence and the conflict between these two mode of transportations in Kota Makassar. It was found that online transportation has become an alternative of transportation for society for a number of reasons: practicality, transparency, trustworthiness, security, insurance, features, discount and promotion rates, as well as new employment/part-time opportunities. The existence of onlinebased transportation has caused a conflict between the two. In one side, online transportation is considered to facilitate drivers and their passangers. On the other side, online transportation got criticised from drivers of conventional transportation due to the fact that the latter is being marginalised by the former. Conflict between the two is commonly base on operating lisence, colour of vehicle plate that significantly impacted on payment of taxes, passangers' recruitment base, and competitive online transportation rates. The rate has becomeone of the advantages of online transportation as well as one of the source of conflicts between conventional and online transportation.
\end{abstract}

Copyright () 2017 ETNOSIA. All rights reserved.

\section{Pendahuluan}

Beberapa tahun terakhir di Indonesia telah mengalami transformasi, termasuk dalam bidang transportasi. Kota Makassar merupakan salah satu kota besar di Indonesia dimana transportasi berkembang dengan pesat. Kemudahan mengakses berbagai hal melalui ponsel pintar (smartphone) membuat beberapa perusahaan menggunakan peluang ini untuk mengembangkan aplikasi 
transportasi berbasis online, seperti Grab, Go-Jek, Uber, dll. Jika dibandingkan Uber, maka Grab dan Go-Jek, jauh lebih 'meledak' digunakan oleh masyarakat di Kota Makassar.

Perubahan model transportasi dari konvensional ke transportasi berbasis aplikasi sangat diminati masyarakat dan ini merupakan suatu bentuk perubahan sosial masyarakat yang menghendaki kemudahan dalam penggunaan moda transportasi. Perubahan-perubahan yang terjadi pada masyarakat merupakan gejala yang normal. Pengaruhnya bisa menjalar dengan cepat ke bagian-bagian dunia lain berkat adanya komunikasi modern (Soekanto 2009:259).

Diantara faktor penyebab dan penunjang perubahan sosial adalah teknologi dan masyarakat itu sendiri. Beralihnya jasa pengguna transportasi konvensional ke transportasi online dipengaruhi oleh faktor kecanggihan alat komunikasi (teknologi) dan keinginan masyarakat yang senantiasa menghendaki kemudahan. Perilaku masyarakat dalam menyikapi perubahan akan menerima jika perubahan itu memberikan keuntungan (seperti dibutuhkan, dapat dipahami dan dikuasai, menguntungkan, tidak merusak prestise, meningkatkan taraf hidup, tidak bertentangan dengan tata nilai di masyarakat).

Survey yang dilakukan oleh Yayasan Lembaga Konsumen Indonesi (YKLI), pada bulan April 2017 terkait dengan keberadaan angkutan umum berbasis online yang tidak tercakup dalam trayek, mengungkap alasan yang dikemukakan oleh masyarakat yang memilih atau menggunakan transportasi online, yakni: murah $(84,1 \%)$, cepat $(81,9 \%)$, nyaman $(78,8 \%)$, dan aman $(61,4 \%)$. Ini menunjukkan bahwa ke-murah-an tarif layanan menduduki rangking pertama pilihan responden. Adapun moda transportasi yang dipilih konsumen adalah transportasi online jenis mobil dan motor (55\%); mobil saja (24\%), dan motor saja $(21 \%)$. Selain itu, Go-Jek menduduki rating tertinggi pilihan konsumen (72,6\%); diikuti oleh Grab (66,9\%); kemudian Uber (51\%), dan terakhir My BlueBird (4,4\%)(Tribunnews 2017). Menariknya, meskipun Uber tidak terlalu populer sebagai layanan transportasi online, ia dipilih oleh $51 \%$ responden, sementara My Bluebird dipilih hanya oleh 4,4\% responden. Ini kemungkinan karena imej Bluebird yang meskipun memiliki 'nama baik' dalam layanan transportasi, namun imej 'mahal' juga melekat padanya, sehingga kurang diminati oleh pengguna layanan transportasi. 
Dalam studinya di Jakarta, Dewanto (2016:2) menunjukkan bahwa ojek online bagi masyarakat di ibukota dianggap sebagai 'pahlawan' yang dapat menembus kemacetan yang semakin parah dan digunakan oleh seluruh lapisan masyarakat, sekaligus membuka lapangan pekerjaan baru bagi masyarakat. Namun, terlepas dari kebutuhan transportasi masyarakat, ojek sebagai moda transportasi berbasis online tidak diatur dalam UU No. 22 Tahun 2009 Tentang Lalu Lintas dan Angkutan Jalan (selanjutnya disebut UU No. 22/2009) (Wulandari 2016:2). Selain itu, menurut Avinda (2016:24) kehadiran dan digemarinya ojek online berdampak pada berkurangnya pendapatan ojek konvensional yang tidak siap berkompetisi.

Peralihan ini memicu terjadinya konflik di antara pengemudi jasa transportasi konvensional (seperti pengemudi angkot, taksi, bentor, dan ojek pangkalan) dan pengemudi transportasi online karena omset yang pertama menurun akibat kalah bersaing dengan yang kedua. Artikel ini berfokus pada konflik yang timbul di antara pengemudi kedua moda transportasi ini.

\section{Metode Penelitian}

Penelitian ini dilakukan antara Juni dan Oktober tahun 2017 di Kota Makassar sebagai salah satu kota tempat beroperasinya pengemudi transportasi konvensional (yakni pengemudi angkutan umum, pengemudi taksi, pengemudi ojek dan bentor) dan transportasi online. Transportasi berbasis aplikasi online difokuskan pada Grab dan Go-Jek mengingat bahwa kedua perusahaan ini paling populer di kota Makassar.

Informan yang berpartisipasi dalam penelitian ini berjumlah 15 orang, yang terdiri atas dua pengemudi Grab dan seorang pengemudi Go-Jek, dua pengemudi angkutan kota, dua pengemudi taksi, dua pengemudi ojek pangkalan, seorang pengemudi bentor, tiga konsumen transportasi online, dan dua konsumen transportasi konvensional, sebagaimana dijabarkan pada Tabel $\mathbf{1}$ berikut ini.

$\begin{array}{llccc}\text { No. } & \text { Nama } & \begin{array}{c}\text { Tabel 1. Informan Penelitian } \\ \text { Umur } \\ \text { (tahun) }\end{array} & \begin{array}{c}\text { Jenis } \\ \text { kelamin }\end{array} & \text { Pekerjaan } \\ \text { 1. } & \text { Tamsil } & 39 & \text { Laki-laki } & \text { Pengemudi Grabbike } \\ \text { 2. } & \text { Acong } & 35 & \text { Laki-laki } & \text { Pengemudi GrabCar } \\ \text { 3. } & \text { Nandar } & 20 & \text { Laki-laki } & \text { Pengemudi Go-Jek } \\ \text { 4. } & \text { Kahar } & 25 & \text { Laki-laki } & \text { Pengemudi Angkutan Kota } \\ \text { 5. } & \text { Ihsan } & 30 & \text { Laki-laki } & \text { PengemudiAngkutan Kota } \\ \text { 6. } & \text { Rusman } & 34 & \text { Laki-laki } & \text { Pengemudi Taksi } \\ \text { 7. } & \text { Syahril } & 37 & \text { Laki-laki } & \text { Pengemudi Taksi } \\ \text { 8. } & \text { Sarifuddin } & 29 & \text { Laki-laki } & \text { Pengemudi Ojek }\end{array}$




$\begin{array}{lllcc}\text { 9. } & \text { Ramli } & 18 & \text { Laki-laki } & \text { Pengemudi Ojek } \\ \text { 10. } & \text { Ahmad } & 37 & \text { Laki-laki } & \text { Pengemudi Bentor } \\ \text { 11. } & \text { Rahmatia } & 32 & \text { Perempuan } & \text { Konsumen GrabCar } \\ \text { 12. } & \text { Mirna } & 28 & \text { Perempuan } & \text { Konsumen GrabCar } \\ \text { 13. } & \text { Fitri } & 35 & \text { Perempuan } & \text { Konsumen Go-Food } \\ \text { 14. } & \text { Natalin } & 20 & \text { Perempuan } & \text { Konsumen Angkutan Kota } \\ \text { 15. } & \text { Arya } & 22 & \text { Laki-laki } & \text { Konsumen Angkutan Kota }\end{array}$

Teknik pengumpulan data dilakukan melalui wawancara mendalam, observasi dan review dokumen. Wawancara mendalam (in-depth interview) dimaksudkan untuk menggali informasi mengenai konflik yang terjadi di antara pengemudi transportasi konvensional dengan pengemudi transportasi online setelah berjamurnya transportasi berbasis aplikasi. Observasi dilakukan selama empat bulan sejak awal saya menggunakan jasa layanan transportasi Grab dan Go-Jek. Observasi juga dilakukan di beberapa tempat mangkal transportasi konvensional. Review dokumen dilakukan untuk mengkaji literatur terkait eksistensi transportasi online dan permasalahannya.

Proses analisis data dilakukan dengan mengumpulkan seluruh data yang dikumpulkan dari teknik pengumpulan data yang berbeda. Ini dilanjutkan dengan mengatur, mengurutkan, mengelompokkan, memberi kode dan mengkategorikannya sesuai dengan tema-tema temuan penelitian, yang meliputi eksistensi transportasi online, masalah yang timbul, dan konflik yang terjadi, aturan-aturan terkait transportasi, dan pendapat masyarakat tentang transportasi berbasis aplikasi.

Sebelum wawancara dilakukan, saya terlebih dahulu menjelaskan tentang maksud dan tujuan penelitian ini. Lalu, ini dilanjutkan dengan menanyakan kepada calon informan tentang kesediaan untuk berpartisipasi dan/atau direkam. Hanya jika mereka bersedia untuk terlibat, maka dilanjutkan dengan wawancara dengan ataupun tanpa direkam. Semua informasi dijaga kerahasiaannya (confidential) dan semua yang berpartisipasi dalam peneltian ini disamarkan namanya (pseudonym).

\section{Keunggulan Transportasi Online}

Perkembangan teknologi secara pesat terutama dalam bidang telekomunikasi di seluruh dunia menyebabkan tiap-tiap negara harus mampu bersaing dengan pemanfaatan teknologi serta mengaplikasikannya di dalam beraktivitas. Dalam bidang transportasi, beralihnya jasa transportasi konvensional ke jasa transportasi online merupakan bagian dari kemajuan teknologi. 
Teknologi diciptakan dengan tujuan untuk mempermudah berbagai aktivitas manusia sehari-hari. Berkaitan dengan ini, kehadiran transportasi online 'menjawab' kebutuhan masyarakat dalam kaitan dengan angkutan umum. Transportasi online - yang dalam konteks ini adalah Grab dan Go-Jek - menjadi alternatif yang banyak digemari oleh masyarakat karena beragam keunggulannya yang mencakup: kepraktisan, transparansi, keterpercayaan, keamanan, kenyamanan, asuransi, ragam fitur, diskon dan promosi (selanjutnya disebut promo), dan lahan kerja baru/sampingan.

Dari segi kepraktisan, layanan jasa transportasi Grab dan Go-Jek yang berbasis aplikasi online ini cukup menggunakan telfon pintar yang berkoneksi internet dan aplikasi jasa transportasi online yang ada di dalamnya, yang melaluinya seseorang dapat melakukan pemesanan layanan jasa transportasi. Mirna (28 tahun) salah seorang konsumen Grab, misalnya, menjelaskan bagaimana praktisnya memesan jasa transportasi melalui aplikasi Grab. Di zaman dimana telfon pintar sebagai sesuatu yang umum digunakan, mereka konsumen tinggal mengunggah melalui play store kemudian mendaftarkan data diri yang dikoneksikan pada alamat email atau facebook. Setelah itu jasa Grab akan dapat diakses kapan saja dan dimana saja.

Dari segi transparansi, jasa transportasi Grab atau Go-Jek ini juga memungkinkan pelanggan mengetahui dengan pasti setiap informasi jasa transportasi online secara detail, seperti nama pengemudi, nomor kendaraan, posisi kendaraan yang akan dipakai, waktu perjalanan, lisensi pengendara dan lain sebagainya. Fitri (35 tahun), salah seorang konsumen Go-Jek, menjelaskan bahwa bila ia memesan Go-Car melalui aplikasi Go-Jek, pengemudi dan plat nomor pengendara akan muncul di layar telfon pintar serta rute yang dilalui oleh pengemudi. Sebelum Go-Car menjemput, pengemudi terlebih dahulu menelfon untuk memastikan bahwa calon penumpang memesan Go-Car. Pengemudi juga menelfon jika ia kebingungan mencari alamat konsumen.

Dari sisi keterpercayaan, pengemudi layanan transportasi online telah terdaftar di perusahaan jasa transportasi online, yang berupa identitas lengkap dan perlengkapan berkendara yang sesuai Standar National Indonesia (SNI), sehingga ini dapat meminimalisir resiko kerugian terhadap pengguna jasa transportasi ini, sebagaimana yang diungkapkan oleh Tamsil (39 tahun, pengemudi GrabBike): 
Kalau kita mau mendaftar Grab, kita disuruh melengkapi SKCK1, KTP2, Kartu Keluarga, Pas Foto, Memiliki Rekening Pribadi dan Smartphone, dan kendaraan bebas pajak. Semua identitas sudah lengkap di kantor, jadi kalau ada penumpang yang merasa tidak nyaman tinggal dia lapor di kantor bahwa driver dengan nama A, misalnya, sudah melakukan tindakan kurang menyenangkan. Langsung dibekukanki akunnya jadi tidak bisa lagi menerima orderan sampai dia melapor di kantor. Jika ada barang penumpang yang tertinggal di GrabCar, penumpang dapat melihat riwayat transaksi dan menghubungi pengemudi mobil yang telah dikendarainya dan pengemudi akan langsung mengantarkan barang penumpang yang tertinggal tersebut (Tamsil, 6 Oktober 2017).

Tingginya minat masyarakat untuk menggunakan transportasi online adalah karena keamanan dari layanan ini. Pengguna jasa transportasi online, terutama perempuan umumnya tidak merasa takut dengan adanya tindakan kriminal seperti pelecehan, pencopetan, dll. yang kerap kali terjadi di angkutan kota (angkot) dan taksi. Ini karena penumpang transportasi online dapat melaporkan ketidaknyamanan pelayanan mereka secara langsung kepada customer office Grab atau Go-Jek. Pengemudi yang melanggar akan ditangguhkan atau dibekukan akunnya (suspend) (lihat Gambar 1), sehingga tidak dapat lagi menerima orderan dan kontrak akan terputus, seperti yang diungkapkan oleh Acong (35 tahun) pengemudi GrabCar, berikut ini:

Kita tidak bisa macam-macam disini bu (di Grab) karena kalo ada konsumen yang protes, terutama dari cara pelayanan, langsung melapor ke kantor akun-ta di-suspend kita ndak bisami lagi terima orderan. Disuspend itu sama dibekukan akunnya, bisa jeki masuk lagi, tapi kalo buat akun baru atas nama orang lain, tapi kendaraan lain yang kita bawa, itu kalo kendaraan yang punya lebih dari satu karena nomor plat kendaraan yang dulu sudah terdaftar.

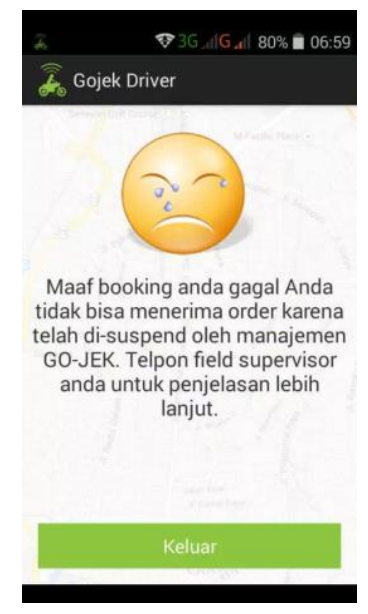

Gambar 1. Akun pengemudi Go-Jek yang ditangguhkan (suspend).

\footnotetext{
${ }^{1}$ SKCK: Surat Keterangan Catatan Kepolisian (dulu disingkat SKKB, Surat Keterangan Kelakuan Baik).

${ }^{2}$ KTP: Kartu Tanda Penduduk.
} 
Gambar 1. menunjukkan laporan langsung dari salah satu perusahaan transportasi online (Go-Jek) terkait kegagalan orderan konsumen karena pengemudinya ditangguhkan oleh manajemen. Laporan semacam ini mengindikasikan bahwa ada pelanggaran yang telah dilakukan oleh pengemudi, sehingga untuk mengetahui secara jelas, maka pengemudi harus berhubungan dengan perusahaan tempatnya bekerja. Respon langsung seperti ini (pembekuan beroperasi) memberikan rasa keamanan bagi pengguna jasa transportasi online.

Dari segi kenyamanan, konsumen transportasi online merasakan tidak sedang berada di dalam angkutan umum karena mobil-mobil yang digunakan (taksi online) menggunakan mobil-mobil pribadi keluaran lima tahun terakhir (20122017, yang memang dipersyaratkan oleh perusahaan) dengan beragam merek (seperti Avanza, Calya, Datsun, Shienta, Agya, dsb.). Salah seorang konsumen GrabCar, Rahmatia (32 tahun), mengungkapkan:

GrabCar itu seperti mobil pribadi jadi kita lebih leluasa di dalamnya tidak sempit, jadi kita bisa pergi ramai-ramai atau bawa barang banyak bayarnya tetap sama. Di dalamnya kita bisa dengar musik, nonton video, ber AC juga, persis kendaraan pribadi apalagi platnya kan hitam. Driver-nya juga ramah sering ajak cerita. Kalo mobilnya kecil atau tidak sesuai bisa dicancel. Kadang tetangga tidak tahu kalo saya naik Grab dan bilang banyaknya itu mobilmu ganti-ganti tiap hari.

Kutipan di atas menunjukkan bahwa kenyamanan tidak saja berkaitan dengan atmosfir di dalam kendaraan, tapi juga berhubungan dengan perasaan mereka yang seakan berada di mobil pribadi dengan berbagai fasilitas penunjangnya. Berbeda dengan transportasi konvensional yang selama ini dinilai sangat tidak nyaman sebagaimana yang diungkapkan Natalin (20 tahun), bahwa konsumen angkot beranggapan jika menggunakan angkot ia akan lama tiba di tempat tujuan karena angkot sering singgah mengambil penumpang. Selain itu, menumpang angkot terasa panas karena angkot sering lama menunggu penumpang lain di pinggir jalan dan berdesak-desakan di dalamnya. Arya (22 tahun), konsumen angkot, menambahkan bahwa angkot yang ditumpanginya terkadang sudah reot dan tidak layak jalan, sehingga rawan akan kecelakaan lalu lintas.

Adanya asuransi kecelakaan bagi pengguna dan pengemudi adalah aspek positif lainnya terkait jasa transportasi berbasis online. Go-Jek telah melakukan kerjasama dengan perusahaan asuransi Allianz dalam memberikan perlindungan asuransi kecelakaan bagi para pengguna jasa transportasi Go-Jek 
(USU 2016:6). Untuk Grab sendiri juga telah bekerjasama dengan Asuransi Marine untuk menjamin keselamatan pekerjanya. Pada kasus kehilangan barang, GoCar bahkan bersedia memberikan bantuan sampai Rp10.000.000,atas pertimbangan pribadi dan mutlak untuk barang yang hilang atau rusak saat menggunakan layanan dari penyedia layanan sepanjang barang tersebut memenuhi ketentuan penggunaan. Sedangkan untuk kasus kecelakaan, GrabCar dapat memberikan asuransi kecelakaan hingga maksimum Rp68.000.000,-/orang (Asuransi Marine 2017: 3).

Keunggulan lainnya yang terkait dengan layanan transportasi Grab dan Go-Jek adalah berbagai fitur yang disediakan oleh kedua jenis transportasi online ini. Grab, misalnya, yang menyediakan fitur aplikasi berupa GrabBike (layanan transportasi motor online/ojek online), GrabCar (layanan mobil pribadi berplat hitam yang disewa untuk perjalanan dari satu tujuan ke tujuan lainnya - point to point atau jam-jaman-dengan tarif flat per kilometer), GrabTaksi (layanan yang difokuskan sebagai wadah bertemunya para pencari jasa taksi dan jaringan penyedia taksi dengan sistem argo) dan GrabExpress (layanan kurir ekspres berbasis aplikasi yang menjanjikan kecepatan, kepastian, dan keamanan). Untuk beberapa kota besar seperti Ibu Kota Jakarta dan sekitarnya, aplikasi Grab telah ditambahkan dengan layanan GrabFood (layanan pesan antar makanan yang telah bekerjasama dengan beberapa restoran), GrabHitch (mempertemukan pengemudi dan penumpang yang memiliki rute perjalanan searah dan terbagi atas dua jenis, yaitu Hitch bike dan Hitch car), Rental, GrabParcel (Layanan kurir dengan waktu pengiriman yang dapat dipilih sesuai dengan kebutuhan konsumen dengan harga yang lebih ekonomis) (Grab 2017). Saat ini perusahaan Grab juga menambahkan fitur GrabFood untuk menyaingi rivalnya Go-Jek yang memberikan layanan pesan antar makanan (GoFood), namun untuk wilayah Kota Makassar hanya terdapat 3 layanan yaitu GrabBike, GrabCar dan GrabTaxi.

Untuk jasa layanan Go-Jek, meskipun menyerupai Grab sebagai jasa transportasi online, namun Go-Jek memiliki variasi fitur yang menunjukkan keunikannya, yaitu selain layanan transportasi motor, mobil dan layanan kurir, Go-Jek juga menambahkan Go-Food (layanan pesan antar makanan No.1 di Indonesia dengan lebih dari 64.000 restoran terdaftar), GoMart (layanan yang dapat digunakan konsumen untuk berbelanja berbagai jenis barang dari berbagai macam toko), GoBox (layanan pindah barang ukuran besar menggunakan truk bak/blind van), GoTix (layanan informasi acara dengan akses pembelian dan pengantaran tiket langsung ke tangan konsumen), GoGlam (layanan kecantikan tanpa harus pergi ke salon), GoClean (layanan 
jasa kebersihan profesional ke rumah atau kantor), GoMassage (layanan jasa pijat kesehatan professional langsung ke rumah), GoMed (layanan terintegrasi untuk membeli obat-obatan, vitamin, dan kebutuhan medis lainnya dari apotek berlisensi), GoPulsa (layanan pengisian pulsa langsung dari aplikasi Go-Jek). Untuk sistem transaksi pada aplikasi Go-Jek konsumen dihadapkan pada dua pilihan yang memudahkan konsumen, yakni GoPay dan Grabpay (yang merupakan layanan dompet virtual untuk transaksi dalam aplikasi Go-Jek) dan sistem bayar langsung (cash). Grab dan Go-Jek juga memberikan program loyalty dimana konsumen bisa mendapatkan token ataupun bonus setiap menggunakan metode GoPay dan GrabPay. Selain itu, Go-Jek memberikan program rujukan yang memungkinkan konsumennya merujuk teman menggunakan GoPay dan mendapatkan reward berupa vocer diskon di beberapa tempat yang bekerjasama dengan kedua aplikasi tersebut (Go-Jek Indonesia 2017). Aplikasi transportasi Go-Jek juga telah menambah layanan baru GoBusway untuk wilayah DKI Jakarta. Go-Busway adalah layanan transportasi ojek untuk mengantar penumpang ke halte bus Transjakarta yang diinginkan. Layanan ini juga terintegrasi dengan Go-Ride untuk pemesanan transportasi menuju ke halte Transjakarta. Layanan terbaru ini konsumen dapat mengetahui informasi bus Transjakarta untuk koridor 1, 2, 6, 8, 9, 10, 11, dan 12 (Liputan6, 2017). Namun, untuk wilayah Makassar aplikasi GoTix, GoLife (GoGlam, GoClean, dan GoMessage), dan Go-Busway hingga kini belum dapat diakses oleh masyarakat.

Nandar (20 tahun, pengemudi Go-Jek) mengungkapkan bahwa dulu jika ia ingin memakan makanan dari restoran atau rumah makan, maka ia harus mendatangi tempat makan, namun sekarang Go-Jek memiliki fitur Go-Food untuk memudahkan konsumen yang ingin memesan makanan tanpa harus mengunjungi secara langsung restoran atau rumah makan (lihat Gambar 2). Hal serupa juga dapat dilakukan jika ingin berbelanja di minimarket atau supermarket karena konsumen dapat memesan melalui Go-Mart atau Go-Shop dan dikirim langsung ke rumah.

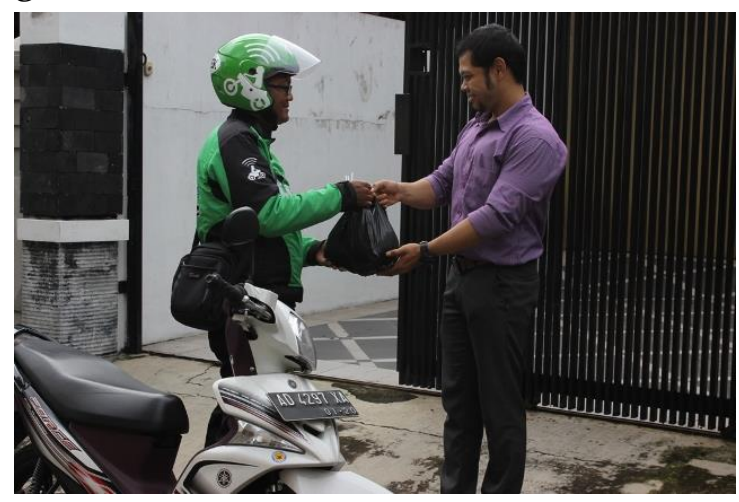

Gambar 2. Pelayanan mengantar makanan dari GoFood 
Saat ini biaya transportasi menjadi sumber pengeluaran yang cukup menyita keuangan. Tingginya mobilitas masyarakat, terutama saat jam-jam kerja, membuat konsumen terkadang harus bergonti-ganti alat transportasi untuk mencapai tujuan, yang secara signifikan meningkatkan pengeluaran. Untuk itu mereka harus menyiasati pengeluaran seminim mungkin. Dalam penggunaan transportasi online, konsumen tidak hanya 'dimanjakan' oleh tarif murah (baca juga sessi berikut terkait ini), tapi juga adanya diskon dan promo menarik. Jika secara rutin konsumen memanfaatkan diskon dan promo transportasi online, maka nilai penghematan biaya transportasi akan 'terasa' di kantong konsumen. Untuk tahun 2017, Grab misalnya, memberikan diskon dan promo yang terdiri dari tiga jenis, yakni: 1) Cashback 100\% jika pertama kali mengisi dana ke GrabPay (misalnya mengisi dana Rp 100.000,- ke GrabPay melalui ATM); internet banking ataupun mobile banking dana yang terisi di GrabPay menjadi Rp 200.000,-. Dana ini biasa digunakan untuk membayar GrabBike, GrabCar, dll; 2) Diskon 60\% atau maksimal Rp10.000,- untuk layanan GrabBike. Diskon ini dapat dinikmati jika melakukan pembayaran dengan metode GrabPay dengan kode Grab60 yang muncul dilayar berikutnya. Setelah itu, akan muncul keterangan mendapatkan potongan 60\% atau maksimal Rp10.000,- yang dipotong dari tarif normal; 3) Tarif 40\% atau maksimal Rp25.000 untuk layanan GrabCar, yang caranya hampir sama dengan diskon pada GrabBike setelah menggunakan kode promo Grab40 yang diikuti dengan konfirmasi potongan harga yang diperoleh (Halomoney 2017: 9-10). Dalam kaitan dengan ini, Mirna mengungkapkan sebagai berikut:

\footnotetext{
Saya lebih senang pakai Grab soalnya banyak diskon dan promo-promonya kan kalo sering kita pake biasa kita dapat poin, itu poin bisa di tukar dengan vocer belanja di toko atau diskon perjalanan biasanya cuma bayar Rp10.000,- saja sekali perjalanan. Kadang juga ada perjalanan gratisnya kalo pointa sudah banyak (Mirna, 28 tahun, konsumen Grab).
}

Serupa halnya dengan Grab, Go-Jek juga berupaya 'memanjakan' pelanggannya dengan memberikan diskon dan promo menarik. Jika Grab memberikan tiga jenis diskon dan promo, maka Go-Jek memberikan diskon dan promo hingga lima jenis, yaitu : 1) diskon 40\% dengan GoRide; 2) diskon 20\% dengan GoCar; 3) diskon 25\% dengan GoSend (layanan pengiriman barang), 4) Freedelivery GoFood; dan 5) diskon 30\% GoTaxi bila menggunakan GoPay. Semua diskon dan promo ini telah berlaku sejak awal Februari 2017 dan telah menjadi daya tarik tersendiri bagi konsumen yang tidak diperoleh dari moda transportasi konvensional. 
Grab dan Go-Jek memang sedang mengembangkan ekspansi bisnisnya ke segala penjuru negeri, sehingga kedua perusahaan ini membutuhkan tenaga kerja. Transportasi online ini dianggap sebagai lahan pekerjaan bagi pengangguran atau kerja sambilan bagi mereka yang telah memiliki pekerjaan karena waktu kerjanya yang fleksibel. Misalnya, pegawai kantoran yang memiliki jam kerja mulai dari pagi hingga sore, maka mereka dapat memanfaatkan waktunya setelah pulang dari kantor untuk mendapatkan penghasilan tambahan. Tidak sedikit anggota masyarakat yang ingin menjadi tenaga kerja pada perusahaan Grab dan Go-Jek, apalagi karena prosedurnya yang relatif mudah. Acong, misalnya, menyatakan bahwa:

\begin{abstract}
Sangat mudah untuk menjadi driver Grab cukup dengan membawa kelengkapan berkas berupa $\mathrm{KK}^{3}$, KTP, SIM ${ }^{4}$, STNK5 , SKCK, memiliki smartphone dan kendaraan pribadi keluaran lima tahun terakhir dan tidak mati pajak. Uang pendaftarannya pun gratis, untuk yang mendaftar sebagai GrabBike akan dikasih atribut berupa jaket dan helm berwarna hijau bertuliskan Grab. Sedangkan untuk mobil (GrabCar) cukup dengan mendownload aplikasinya. Tidak ada pembatasan kendaraan bila ingin mendaftar dan waktu kerjanya juga fleksibel (Acong, 35 tahun, pengemudi Grab).
\end{abstract}

Kemudahan pendaftaran sebagaimana yang dikemukakan oleh Acong di atas membuat masyarakat banyak yang tergiur untuk bergabung menjadi pengemudi pada perusahaan-perusahaan penyedia transportasi online, seperti Grab dan Gojek.

Aspek-aspek sebagaimana yang dikemukakan di atas merupakan 'nilai tambah' layanan transportasi online (Grab dan Go-Jek) dan menjadi moda alternatif transportasi yang dibutuhkan masyarakat yang sebelumnya menggunakan model transportasi konvensional dengan beragam masalah, terutama yang terkait dengan ketidakamanan dan ketidaknyamanan, dll.

\title{
4. Pro-Kontra Online vs Konvensional
}

Munculnya transportasi berbasis aplikasi telah menimbulkan pro dan kontra di masyarakat. Di satu sisi transportasi online dianggap mempermudah pengemudi dan konsumennya. Disisi lain, transportasi online mendapatkan banyak kecaman dari pengemudi transportasi konvensional karena dianggap sebagai transportasi illegal dan merebut nafkah para pengemudi jasa transportasi konvensional.

\footnotetext{
${ }^{3}$ KK: Kartu Keluarga

${ }^{4}$ SIM: Surat Izin Mengemudi

${ }^{5}$ STNK: Surat Tanda Nomor Kendaraan
} 
Ada beberapa permasalahan yang sering dikeluhkan oleh pengemudi transportasi konvensional terkait dengan beroperasinya transportasi berbasis aplikasi, yakni izin operasi, warna plat kendaraan, tempat mengambil penumpang, dan tarif.

\subsection{Izin Operasi}

Selama ini transportasi online tidak memiliki izin (illegal) untuk beroperasi yang menjadi salah satu aspek yang memunculkan konflik berkepanjangan di antara pengemudi transportasi online dan kovensional.

Pemerintah sebenarnya telah menerbitkan aturan terkait transportasi pada UU No. 22/2009 (pasal 11:1a), bahwa akan dilakukannya penyusunan rencana dan program pelaksanaan pengembangan teknologi kendaraan bermotor. Namun karena undang-undang ini tidak secara spesifik mengatur masalah transportasi online, maka dibuatlah Peraturan Menteri Perhubungan Republik Indonesia Nomor 32 Tahun 2016 Tentang Penyelenggaraan Angkutan Orang Dengan Kendaraan Bermotor Umum Tidak Dalam Trayek (selanjutnya disebut Permenhub No. 32/2016) yang secara khusus mengatur penyelenggaraan angkutan umum dengan aplikasi berbasis teknologi informasi (Dephub 2016:7). Namun, ini kemudian direvisi kembali pada tanggal 1 April 2017 menjadi Peraturan Menteri Perhubungan Republik Indonesia Nomor 26 Tahun 2017 (selanjutnya disebut Permenhub No. 26/2017) karena dianggap terlalu berpihak kepada transportasi konvensional. Peraturan tersebut berisi 11 poin revisi yang dibahas dan disepakati bersama antar para pemangku kepentingan dari semua sektor, empat poin diantaranya diberlakukan secara langsung pada 1 April 2017: (1) penetapan angkutan online sebagai angkutan sewa khusus, (2) persyaratan kapasitas silinder mesin kendaraan minimal $1.000 \mathrm{CC}$, (3) persyaratan keharusan memiliki tempat penyimpanan kendaraan, dan (4) kepemilikan atau kerjasama dengan bengkel yang merawat kendaraan (Dephub 2017a:22-24). Sementara untuk pengujian berkala (KIR) kendaraan, stiker dan penyediaan akses Digital Dashboard; maka masa transisi diberikan waktu 2 bulan setelah 1 April 2017, yakni tertanggal 1 Juni 2017. Untuk pemberlakuan poin penetapan tarif batas atas dan batas bawah, kuota, pengenaan pajak, dan penggunaan nama pada STNK, masa transisi diberikan selama 3 bulan untuk pemberlakuannya (Ayuwuragil 2017:4). Hanya saja aturan terkait transportasi online masih menuai pro dan kontra hingga saat ini karena pengemudi transportasi online menganggap penggunaan stiker dan dasbor digital pada kendaraan pribadi dianggap tidak diperlukan. 
Sebagai respon terhadap semakin memanasnya konflik antar pengemudi moda transportasi konvensional dan online yang ditampilkan melalui demonstrasi tanggal 1 November 2017 oleh pengemudi angkutan umum (angkot), taksi, ojek dan bentor, maka pemerintah kembali merevisi Permenhub No. 26/2017 menjadi Permenhub No. 108 Tahun 2017. Ada sembilan poin revisi dalam aturan baru tersebut yang meliputi argometer taksi, tarif, kuota, wilayah operasi, perencanaan kebutuhan kendaraan, persyaratan minimal kepemilikan kendaraan, bukti pemilikan kendaraan bermotor domisili $\mathrm{TNKB}^{6}$, pemenuhan adanya salinan SRUT ${ }^{7}$ dan peran aplikator. Namun untuk pembatasan wilayah operasi, Menteri Perhubungan menyatakan, bahwa kewenangan tersebut diberikan pada pemerintah daerah (Dephub 2017b:2).

Aturan pemerintah terkait transportasi online pada Permenhub No. 108/2017 mengkategorikan GrabCar dan GoCar sebagai angkutan sewa khusus (taksi online). Taksi selama ini merupakan angkutan umum yang melayani penumpang tidak dalam trayek dan memiliki ciri-ciri adanya identitas di tubuh kendaraan, berplat kuning dan memakai argometer. Sedangkan pada taksi online yang selama ini dikenal masyarakat tidak memiliki identitas khusus, berplat hitam, dan tidak memiliki argometer.

Untuk mengakomodir jenis angkutan yang demikian, maka dalam Permenhub No. 108/2017 dibuat nomenklatur angkutan sewa khusus atau angkutan sewa online. Artinya secara hukum pemerintah mengakui keberadaan angkutan yang berbasis aplikasi tersebut. Permenhub No. 108 Tahun 2017 diterbitkan oleh Kementerian Perhubungan menyusul tindak lanjut dari putusan Mahkamah Agung No. 37/P.HUM/2017 tanggal 20 Juni 2017 yang mencabut sebagian ketentuan dalam Permenhub No. 26/2017. Dengan demikian Permenhub No. 108/2017 merupakan peraturan terbaru yang terkait angkutan umum berbasis aplikasi (Dephub 2017b:3).

Meskipun aturan Permenhub No.108/2017 telah diberlakukan, namun di lapangan aturan baru ini masih saja menuai konflik. Ini karena adanya aturan yang dinilai seharusnya dihilangkan yang dimunculkan kembali pada aturan baru ini. Namun, berbeda dengan yang sebelumnya, kali ini yang keberatan adalah pengemudi transportasi online. Keberatan tersebut berkaitan dengan aturan pemasangan stiker sepanjang $15 \mathrm{~cm}$ yang dinilai akan menghilangkan keistimewaan transportasi online sebagai kendaraan pribadi; kewajiban memiliki SRUT; dan penentuan tarif dasar taksi online yang ditentukan secara

\footnotetext{
6 TNKB: Tanda Monor Kendaraan Bermotor.

${ }^{7}$ SRUT: Sertifikat Registrasi Uji Tipe.
} 
sepihak yang dianggap merugikan pengemudi taksi online. Sementara aturan untuk ojek online sendiri sampai saat ini masih sulit dibuatkan regulasi ojek daring. Dalam UU No. 22/2009, kendaraan roda dua sebagai angkutan umum memang tidak diperkenankan beroperasi karena rentan terjadinya kecelakaan, dsbnya. Pemerintah Kota Makassar belum mengizinkan pengoperasian layanan transportasi massal ojek online (Grabbike dan Go-Jek) didalam wilayah Kota Makassar karena menurut Wakil Wali Kota Makassar, Syamsu Rizal MI landasan hukum ojek online belum jelas. Manager Go-Jek Makassar, Rama juga mengajui jika izin operasional ojek online belum ada, berbeda dengan kendaraan roda empat yang telah memiliki izin. Hanya saja Rama menambahkan bahwa ojek online berada di bawah naungan aplikasi bukan perusahaan ojek. PT Go-Jek sendiri telah memiliki legalitas sebagai perusahaan transportasi online, namun aturan terkait operasionalnya masih harus di godok agar masuk dalam Undang-Undang (Ronalyw 2015:4-5).

\subsection{Plat Hitam vs Plat Kuning}

Masalah lainnya adalah terkait dengan penggunaan plat hitam atau plat kuning. Sebelum terbitnya Permenhub No.108 tahun 2017, di dalam UU No. 22/2009 (pasal 47:3) disebutkan dengan jelas bahwa kendaraan bermotor berdasarkan fungsinya terbagi menjadi 1) Kendaraan Bermotor Umum (plat kuning) dan 2) Kendaraan Bermotor Perseorangan (plat hitam) (Dephub 2009). Oleh karena kata 'fungsi' di pasal tersebut memiliki arti yang sama untuk Kendaraan Bermotor Umum (plat kuning) dan Kendaraan Bermotor Perseorangan (plat hitam), maka jelas kata 'fungsi' yang dimaksud di sini bukan ditujukan bagi Kendaraan Bermotor Perseorangan (plat hitam), tapi kendaraan bermotor yang diubah bentuk atau desainnya untuk dijadikan angkutan orang. Biasanya bentuk dan desain kendaraan bukan standar dari ATPM $^{8}$ kendaraan. ATPM hanya menjual kendaraan dalam bentuk sasis (mesin dan kerangka). Bis, mini bis (Metromini, Kopaja), angkutan perkotaan (angkot), dan bajaj termasuk ke dalam kategori ini. Lalu apakah UU No. 22/2009 (pasal 1:10) dapat dijadikan rujukan untuk mengkategorikan Kendaraan Bermotor Perseorangan (plat hitam) menjadi Kendaraan Bermotor Umum (plat kuning) karena telah memungut bayaran ke pengunanya? Memungut bayaran dengan menggunakan Kendaraan Bermotor Perseorangan (plat hitam) tidak serta merta mengubah statusnya menjadi Kendaraan Bermotor Umum (plat kuning) (Julianto 2016:3).

\footnotetext{
${ }^{8}$ ATPM: Agen Tunggal Pemegang Merek
} 
Acong (35 tahun), yang seorang pengemudi GrabCar, mengungkapkan:

GrabCar sering dipermasalahkan sama pengemudi angkot dengan taksi karena dianggap yang kami pake plat mobil pribadi (plat hitam) bukan kayak angkutan umum yang ber plat kuning. Kami dianggap tidak bisa mengambil penumpang di jalan karena tidak resmi. Biasa sudah dapat penumpang dipaksa lagi kasih turun kalau ketahuan (Acong, 28 September 2017) (lihat Gambar 3).

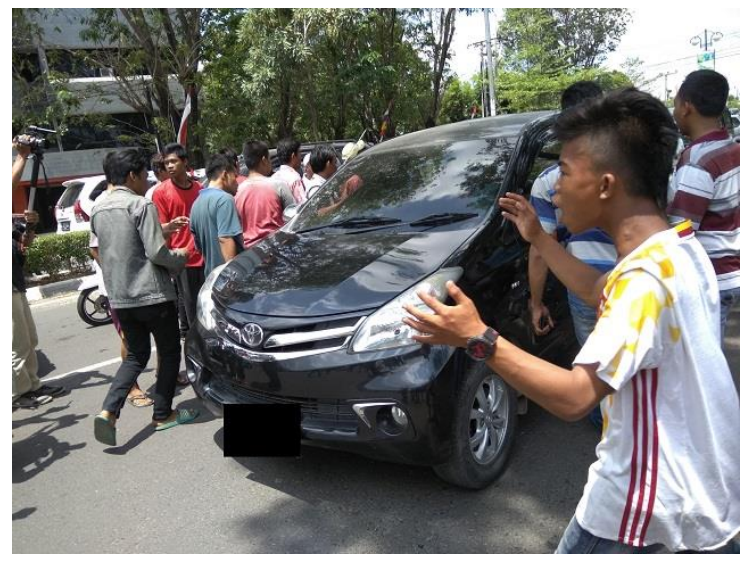

Gambar 3. Razia transportasi online

Razia transportasi online yang dilakukan oleh para pengemudi transportasi konvensional terjadi di depan Kantor Gubernur Makassar pada tanggal 1 November 2017. Ini merupakan puncak dari konflik yang berlarut-larut karena transportasi online dianggap beroperasi secara illegal. Oleh karenanya ketika menemukan mobil berplat hitam yang mengangkut penumpang, pengemudi transportasi konvensional memaksa agar penumpang turun. Akibat aksi tersebut, para penumpang terlantar dan harus berjalan kaki. Aksi ini seringkali berujung anarkis dengan merusak kendaraan (lihat Gambar 4).

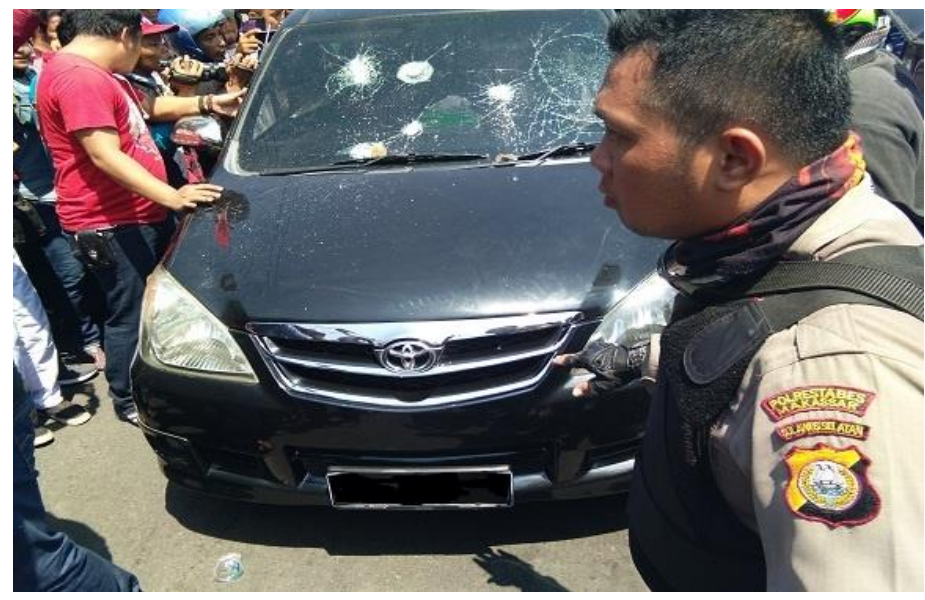

Gambar 4. Pengrusakan GrabCar 
Gambar 4 menunjukkan pengrusakan kendaraan transportasi online (GrabCar) yang dilakukan oleh pengemudi transportasi konvensional yang menuntut penutupan transportasi berbasis aplikasi tersebut. Aparat keamanan tidak mampu menghalau demonstran yang melakukan tindakan pengrusakan pada tanggal 1 November 2017 di depan Kantor Gubernur. Aksi mogok ratusan pengemudi angkutan kota (angkot) sebelumnya juga pernah terjadi di Jalan Sultan Alauddin Makassar sebagai bentuk protes dan penolakan terhadap transportasi berbasis online (HeadlineNews Metro TV, 5 Februari 2017). Selain itu, mereka juga menolak kenaikan tarif administrasi kendaraan yang beroperasi di Makassar. Dalam aksinya para pengemudi transportasi konvensional melakukan mogok operasi dan sweeping terhadap transportasi online yang beroperasi. Selain melakukan mogok operasi dan sweeping, pengemudi angkot konvensional tersebut juga mendatangi Kantor Wali Kota Makassar untuk menanggapi permintaan mereka.

UU No. 22/2009 tidak mengatur penggunaan Kendaraan Bermotor Perseorangan (plat hitam) karena kendaraan ini masuk kategori hak milik pribadi (private property), dan negara tidak memiliki kewenangan terkait penggunaan atau pemakaian hak milik pribadi seseorang. Tapi negara mengatur segala sesuatu yang menyangkut kepentingan publik. Segala sesuatu yang menyangkut penggunaan dan pemakaian hak milik pribadi dasar hukumnya adalah Undang-Undang Hukum Perdata (KUHPer) dan Kitab Undang-Undang Hukum Pidana (KUHP) (Julianto 2016:2).

Upaya Kementerian Perhubungan untuk mengarahkan Kendaraan Bermotor Perseorangan (plat hitam) berbasis aplikasi menjadi Kendaraan Bermotor Umum (plat kuning) adalah upaya yang berlebihan. Selain mencampuri urusan kepemilikan kendaraan pribadi, upaya ini juga dapat membuka peluang terjadinya praktek pungutan liar (pungli), sehingga membuat biaya ekonomi tinggi seperti yang terjadi pada jasa usaha transportasi konvensional. Kahar (25 tahun, pengemudi angkot):

Saya tidak setuju kalau itu kendaraan plat hitam (transportasi online) itu bebas ambil penumpang di jalan, kan dia aplikasi dipesan sama orang baru datang, tapi kalo seenaknya mau ambil penumpang di jalanan, saya tidak senang, sama-sama jeki butuh makan toh. Kita ini angkot kan sudah jelas trayeknya, tarif penumpang juga sudah ditentukan sama ORGANDA ${ }^{9}$ kita tidak bisa kasih naik atau kasih turun sendiri (Kahar, 21 Oktober 2017).

Apa yang dikemukakan oleh Kahar cukup beralasan mengingat sistem pelayanan transportasi online adalah berbasis aplikasi online, sehingga jika

\footnotetext{
${ }^{9}$ ORGANDA: Organisasi Pengusaha Angkutan Darat.
} 
pengemudi mengambil penumpang di jalanan, maka ini serupa dengan sistem pelayanan transportasi konvensional. Ia yang merupakan pengemudi angkot mengakui bahwa ia rajin membayar pajak jalan pada Dinas Perhubungan karena mobilnya merupakan angkutan umum yang menggunakan plat kuning, sedangkan Grab dianggap tidak dikenai pajak jalan karena menggunakan plat hitam dan bebas berkeliaran mencari penumpang.

Dalam kaitan dengan ini, Grab Indonesia menampik tudingan dari taksi konvensional yang menyatakan perusahaannya illegal dan tak memenuhi aturan. 'Kami merupakan entitas legal dan terdaftar sebagai pembayar pajak di Indonesia', kata Managing Director Grab Indonesia, Ridzki Kramadibrata (Selasa, 22 Maret 2016). Artinya pihak Grab menganggap dirinya sebagai perusahaan legal atas dasar pembayaran pajak tersebut. Menurut Ridzki, Grab juga proaktif berkomunikasi dengan pemerintah untuk mendapatkan legalitas dan menyediakan layanan efisien bagi masyarakat dan semua mitra pengemudi yang tergabung dalam jaringan Grab telah melalui proses seleksi dan pelatihan yang ketat. Selain itu, Grab juga telah menyediakan asuransi tidak saja bagi pengemudi, tapi juga bagi penumpang (Hidayat 2016:4).

Rusman (30 tahun, pengemudi taksi) juga mendukung pendapat Kahar (di atas), yang tidak menyetujui jika transportasi online ber plat hitam diizinkan beroperasi di jalan, sebagaimana yang dikemukakan Rusman berikut ini:

Kita ini sopir taksi lama-lama banyak yang jadi penggangguran kalau begini, orang sudah lebih banyak yang memilih aplikasi dibandingkan taksi karena dianggap lebih murah. Padahal taksi kan sudah resmi karena kita bayar pajak, kan untuk pengurusan STNK saja itu beda kalau mobil pribadi sama angkutan umum, beda STNKnya. Orang banyak yang bilang taksi mahal karena pake argo, baru buka pintu argo sudah jalan beda sama online yang bisa pasang tarif lebih murah. Biar Grab kerjasama dengan taksi, masyarakat tetap lebih banyak yang gunakan aplikasi karena murah dan mereka juga biasa mangkal di tempatta ambil penumpang seperti mal dan rumah sakit (Rusman, 21 Oktober 2017).

Dari sudut pandang pengemudi transportasi konvensional (taksi dan angkot), jika transportasi online merasa telah secara resmi terdaftar pada Dinas Perhubungan, maka mereka berhak mendapatkan plat kuning sebagai tanda angkutan umum. Pada kenyataannya mereka tetap ber plat hitam. Tarif pembayaran pajak transportasi angkutan umum ber plat kuning pada Dinas Perhubungan juga akan berbeda dengan transportasi ber plat hitam. 
Sebenarnya penyelenggaraan taksi online atau angkutan berbasis aplikasi telah dijabarkan sebelumnya dalam Bab IV Permenhub No. 32/2016. Salah satu klausulnya menyebutkan bahwa perusahaan jasa angkutan tidak dalam trayek, misalnya taksi, diperbolehkan memakai aplikasi. Penyediaan aplikasi bisa dilakukan sendiri atau bekerja sama dengan perusahaan aplikasi yang sudah berbadan hukum Indonesia. Sistem pembayaran angkutan tersebut juga boleh disematkan sekaligus dalam aplikasi sepanjang ia tetap mengikuti ketentuan di bidang informasi dan transaksi elektronik. Bila perusahaan angkutan umum, seperti taksi, bekerja sama dengan perusahaan aplikasi, perusahaan aplikasi tidak dapat bertindak sebagai penyelenggara angkutan, seperti mengatur tarif, merekrut pengemudi, dan menentukan besaran penghasilan pengemudi (Iswanto 2017:6).

\subsection{Tempat Mengambil Penumpang}

Perdebatan lainnya adalah bahwa transportasi konvensional juga lebih banyak menunggu penumpang, sedangkan transportasi online menjemput penumpang dengan tarif yang lebih murah dari transportasi konvensional. Ihsan (30 tahun, pengemudi angkutan kota) mengungkapkan bahwa omsetnya mulai berkurang setelah munculnya transportasi online, yang dulunya penumpang bisa penuh dalam angkotnya, sekarang terkadang hanya empat orang sekali trayek. Selain pengemudi angkot, demonstrasi juga dilakukan oleh para pengemudi ojek pangkalan yang merasa dirugikan oleh ojek online yang kerap mengambil penumpang di wilayah dimana terdapat tempat mangkal bentor dan ojek (lihat Gambar 5).

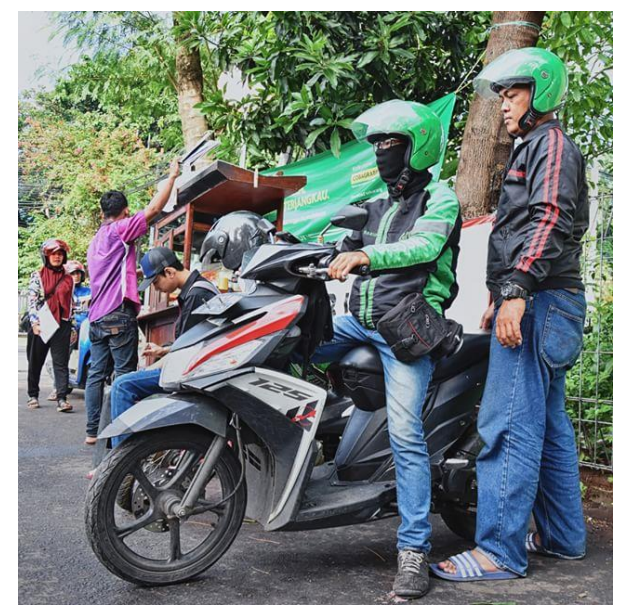

Gambar 5. Go-Jek yang mengambil penumpang disekitar tempat mangkal ojek.

Serupa dengan pengemudi ojek, pengemudi bentor juga melakukan aksi protes atas eksistensi transportasi berbasis aplikasi (lihat Gambar 6). Ahmad (37 tahun, pengemudi bentor) mengemukakan bahwa jika dulunya ibu-ibu kalau 
ke pasar menggunakan bentornya, maka sejak adanya Grab, ibu-ibu beralih jenis transportasi ke Grab, padahal banyak bentor di sekitar lingkungan tempat tinggal mereka.

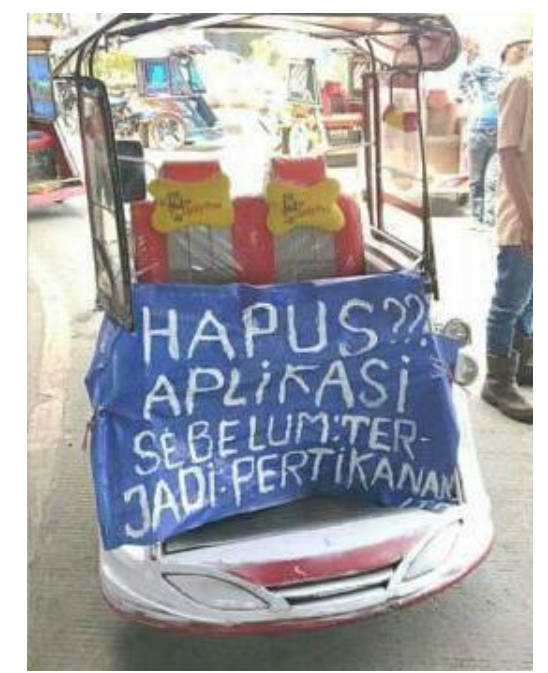

Gambar 6. Spanduk seruan penghapusan transportasi online.

Tidak mengherankan jika di tempat-tempat tertentu pelarangan keras pengambilan penumpang dispandukkan peringatan terhadap pengemudi transportasi online, seperti yang terjadi di sekitar Kampus UKI Paulus dan Perintis Kemerdekaan 7 (lihat Gambar 7). Sarifuddin (29 tahun, ojek) mengemukakan bahwa:

Kalau kita disini (Kampus UKI Paulus) sudah lama tidak senang dengan Grab atau Go-Jek, makanya tidak berani mereka ambil penumpang di sini kalau nekad kami juga tidak segan-segan bertindak, disini sudah jelas ada pangkalan ojek kalau mereka berani ambil penumpang disini berarti kami disini tidak dihargai. Di Jalan Perintis 7 juga itu mereka dilarang masuk ambil penumpang.
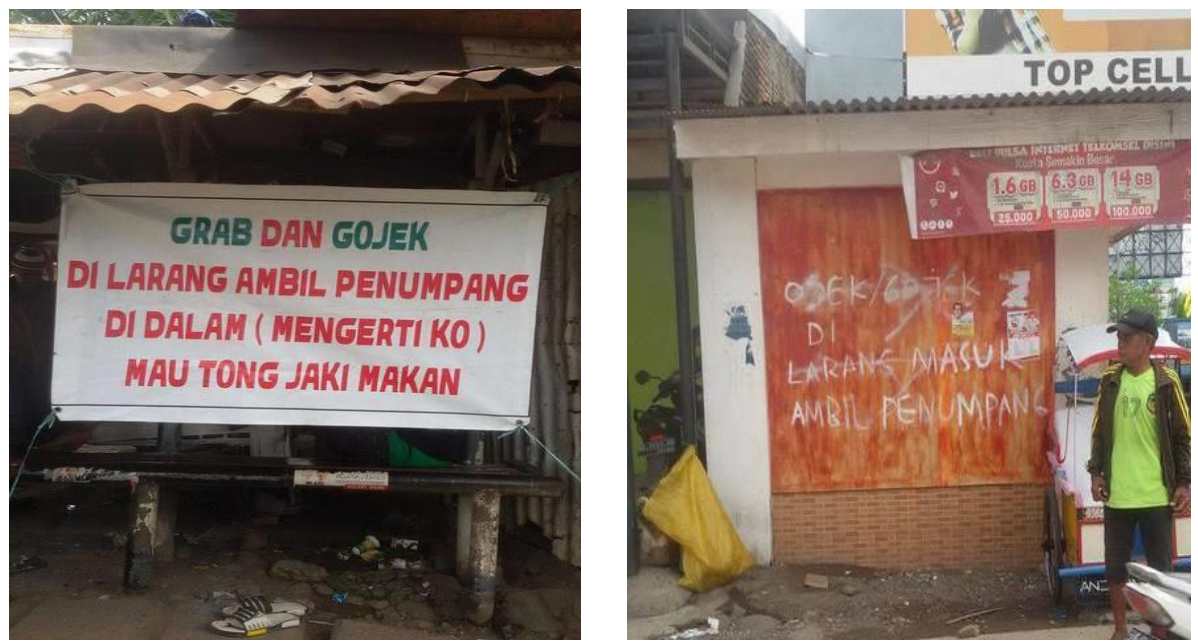

Gambar 7. Larangan transportasi online beroperasi di kawasan tertentu. 
Gambar 7 menunjukkan spanduk 'peringatan' di dua tempat yang berbeda, yaitu tempat mangkal bentor di Jalan Perintis 7 Makassar (kiri) dan di pangkalan ojek sekitar kampus UKI Paulus Makassar (kanan), sebagai spot pelarangan beroperasi transportasi online di sekitar kedua tempat tersebut.

Ramli (18 tahun, pengemudi ojek) juga menjelaskan bahwa perselisihan yang sering terjadi diantara transportasi konvensional dan transportasi online adalah karena transportasi online dinilai seenaknya mengambil penumpang di sekitar tempat mangkal ojek pangkalan ataupun bentor. Ini terkadang menimbulkan permasalahan, seperti pemukulan bahkan penikaman karena mereka merasa 'piring nasi' mereka terganggu oleh moda transportasi online (Ramli, 8 Oktober 2017).

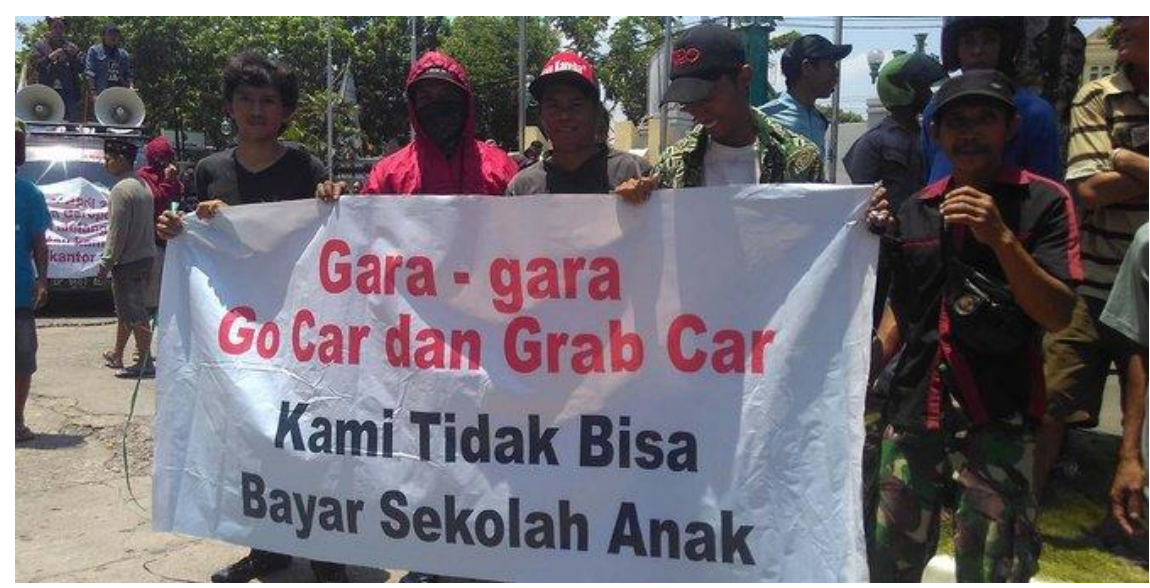

Gambar 8. Spanduk protes para pengemudi angkot atas transportasi online

Penolakan terhadap transportasi berbasis aplikasi kembali terjadi pada tanggal 1 November 2017 yang bertempat di beberapa titik demontrasi seperti fly over. Ribuan sopir transportasi konvensional (khususnya angkot) mengancam akan melakukan mogok massal apabila keinginan mereka tidak ditindak lanjuti. Mereka menganggap bahwa transportasi online selama ini dinilai telah sangat merugikan sopir angkot hingga untuk membayar sekolah anak saja mereka merasa kesulitan (lihat Gambar 8). Mereka meminta agar pemerintah kota Makassar memberikan rekomendasi dan larangan operasional transportasi online. Selama ini transportasi online dinilai oleh seluruh pengemudi transportasi konvensional masih belum memiliki aturan yang baku (ilegal). Sebenarnya pemerintah telah mengeluarkan aturan terkait transportasi online. Dalam Permenhub No. 32/2016, total ada 11 butir regulasi baru yang fokus pada masalah taksi online yang masuk sebagai angkutan sewa khusus. Namun aturan tersebut dianggap tidak menyelesaikan permasalahan yang selama ini terjadi dan pemerintah dianggap cenderung berpihak kepada transportasi 
konvensional karena adanya upaya penyamaan tarif dan pembatasan kuota bagi transportasi online.

Dalam kasus perselisihan transportasi online dan transportasi konvensional, pengemudi transportasi online (seperti Grab dan Go-Jek) sering diintimidasi oleh pengemudi transportasi konvensional, terutama oleh pengemudi bentor dan ojek yang sering dianggap 'mencari masalah', sehingga terjadi pertikaian yang berujung anarkis. Ridwan (32 tahun, pengemudi GraBbike) mengemukakan bahwa:

Kita ini Grab sama Go-Jek sering dicari-carikan masalah, biasa yang bikin itu tukang bentor dan ojek pangkalan, kadang kami di hadang atau kayak kemarin ada cewek driver Go-Jek yang dibakar atributnya di BTP sama ojek pangkalan. Baru-baru ini adalagi teman sesama pengemudi Grab yang ditikam di Maccini, dia di pesan sama tukang bentor baru diarahkan ke dalam lorong-lorong sepi disana dia ditikam (Ridwan, 13 Oktober 2017).

Pengemudi transportasi online seringkali merasa terancam bila memasuki kawasan dimana terdapat pangkalan bentor dan ojek karena seringkali atribut dipreteli, kendaraan dirampas, dll. Sebagai akibatnya, banyak diantara pengemudi Grab atau Go-Jek yang enggan menggunakan atribut perusahaan yang menjadi cirri khas mereka karena kekhawatiran akan adanya tindakan anarkis yang menimpa mereka.

Namun, ini menimbulkan dilemma di antara pengemudi karena, di satu sisi, mereka mendapat teguran dari kantor jika tidak menggunakan atribut perusahaan; di sisi lain, keselamatan diri dan penumpang terancam. Namun, dalam situasi 'panas' (ketika terjadi razia atau demonstrasi), mereka lebih memilih untuk tidak menggunakan atribut hingga situasi menjadi 'aman' kembali.

\subsection{Perang Tarif}

Perang tarif diantara transportasi online dan transportasi konvensional adalah aspek lainnya yang menimbulkan konflik. Transportasi online dinilai telah memasang tarif yang dianggap jauh lebih murah dari transportasi konvensional. Tarif transportasi online yang murah dinilai terancam mematikan omset transportasi konvensional. Para pemberi jasa transportasi konvensional menilai transportasi berbasis aplikasi telah memonopoli harga. Oleh karenanya, penumpang lebih memilih menggunakan transportasi online dibandingkan transportasi konvensional. 
Kemurahan tarif juga banyak dikemukakan oleh konsumen. Rahmatia (32 tahun) konsumen GrabCar, misalnya, mengemukakan bahwa untuk jarak 7,1 km yang ditempuh dari Tamalanrea ke Sudiang Raya tarif GrabCar sekitar Rp30.000an, sedangkan untuk taksi konvensional, penumpang membayar sekitar Rp50.000,-an atau bahkan lebih karena tarif argo taksi konvensional tidak flat. Ini dipertegas oleh Syahril (37 tahun), seorang supir taksi konvensional, yang mengemukakan bahwa satu kali trayek dari Bandara Sultan Hasanuddin ke jalan A.P. Pettarani, tarif taksi konvensional sekitar Rp150.000,-, sementara dengan menggunakan taksi online tarif yang dibayarkan hanya berkisar antara Rp70.000,- dan Rp80.000,- tanpa dikenakan pajak. Artinya, tarif transportasi konvensional dua kali lipat dibandingkan dengan tarif transportasi online.

Beberapa konsumen transportasi online beranggapan lebih menyukai menggunakan transportasi berbasis aplikasi tidak hanya karena tarifnya yang lebih murah, tapi juga terkait dengan keamanan dan kenyamanan. Mirna (28 tahun, konsumen GrabCar), misalnya, mengemukakan kesan positifnya terkait dengan Grab sebagai salah satu tranportasi online, berikut ini:

Saya sering menggunakan GrabCar kalau mau berangkat atau pulang kerja karena kebetulan kendaraan lagi masuk bengkel. Soalnya murah terus kendaraannya juga nyaman. Kalau pakai GrabCar biar pulang malam saya tidak merasa takut, soalnya pengemudinya kan sudah terdata semua identitas lengkapnya. Kalau pulang naik angkot saya takut apalagi kalau sendirian, walaupun tarif angkot lebih murah dari GrabCar (Mirna, 9 Agustus 2017).

Menteri Perhubungan, Ignasius Jonan [Periode Oktober 2014-Juli 2016] menjelaskan bahwa tarif yang diberlakukan pada taksi konvensional mengacu kepada batas atas dan bawah sesuai peraturan pemerintah daerah setempat. Sedangkan untuk transportasi online (GrabCar dan Go Car) ber plat hitam diklasifikan sebagai kendaraan rental yang tarifnya ditetapkan oleh masingmasing penyewa (dalam Nirmala 2016:43). Direktur pelaksana Grab Indonesia, Ridzki Kramadibrata, menolak anggapan pihaknya telah melakukan monopoli harga sehingga menimbulkan skema persaingan yang tidak sehat. 'Kalau harga murah itu relatif, karena kami menyocokkan suplai dan permintaan di sini', kata Ridzki. Oleh karenanya, ada kesepakatan harga antara pengemudi dan penumpang. Di sisi lain, terlepas dari beban tarif yang ditentukan oleh Perda setempat, biaya yang dipungut oleh transportasi umum konvensional, misalnya taksi, seharusnya dapat ditekan (dalam Nirmala 2016:4). Artinya, melalui Perda pemerintah setempat dapat menentukan tarif secara lokal. 
Untuk wilayah Makassar, ketua ORGANDA Makassar, Zaenal Abidin, merespon positif Permenhub No. 26/2017, bahwa revisi Permenhub menjawab sejumlah keinginan pihak penyedia jasa angkutan konvensional. Misalnya, pada BAB II Tentang Jenis Pelayanan Angkutan Orang Dengan Kendaraan Bermotor Umum Tidak Dalam Trayek, Pasal 5 ayat 1f yang mengatur mengenai tarif taksi daring (Dephub 2017a). Penetapan tarif berpedoman pada batas atas dan batas bawah, yang dapat diusulkan oleh gubernur di masing-masing daerah. Pada poin lain diatur soal kuota taksi daring. Selain itu, domisili Tanda Nomor Kendaraan Bermotor (TNKB) yang harus sesuai wilayah operasi karena menurut Zaenal banyak transportasi online yang menggunakan kode plat luar (Makassar), seperti B (plat Jakarta) dan L (Surabaya), dll. (Pranata 2017:4). Syahril (37 tahun, sopir taksi) mempertegas apa yang dikemukakan oleh ketua ORGANDA, bahwa taksi konvensional sudah sangat merugikan pengemudinya sejak munculnya taksi online karena adanya penurunan omset, yakni sekitar $30 \%$.

\section{Kesimpulan}

Di Kota Makassar, transportasi telah berkembang semakin berkembang. Masyarakat yang awalnya hanya menggunakan transportasi konvensional (angkot, taksi, bentor, dan ojek) dihadapkan pada pilihan moda transportasi baru, yaitu transportasi berbasis aplikasi atau yang dikenal sebagai 'transportasi online'.

Kepraktisan, transparansi, keterpercayaan, keamanan, kenyamanan, asuransi, ragam fitur, diskon dan promo, serta ketersediaan lahan kerja baru/sampingan merupakan ragam alasan yang dikemukakan oleh konsumen untuk memilih moda transportasi online. Pemesanan alat transport via aplikasi di telfon pintar memberikan kepraktisan kepada konsumen dalam penggunaan transportasi online. Transparansi identitas pengemudi dan kendaraan serta posisi rute transportasi online membuat konsumen berkendara dengan kejelasan. Kendaraan yang berstandar dan ketersediaan customer service membangun keterpercayaan konsumen dalam penggunaan moda transportasi online. Penggunaan transportasi online memberikan kenyamanan terhadap konsumen karena mereka merasa tidak sedang menggunakan angkutan umum, melainkan seakan berkendara dengan 'mobil pribadi'. Ini semakin diperkuat dengan adanya asuransi kehilangan barang di kendaraan dan asuransi kecelakaan bagi pengemudi maupun penumpang transportasi online. Apa yang membuat transportasi online ini semakin menunjukkan keunikannya adalah ketersediaan ragam fitur yang seperti 'gayung bersambut' bagi konsumen. Tarif transportasi online yang relatif lebih murah dibandingkan dengan transportasi konvensional 
serta diskon dan promo membuat konsumen semakin melirik untuk menggunakannya. Kehadiran transportasi online ibarat 'lahan kerja' baru bagi mereka yang pengangguran dan sebagai pekerjaan sampingan bagi mereka yang telah memiliki pekerjaan tetap jam kerja transportasi online yang fleksibel.

Kemunculan transportasi berbasis aplikasi online di Kota Makassar, di satu sisi, telah memberikan dampak yang signifikan bagi masyarakat dalam pemenuhan kebutuhan transportasi yang praktis, aman, nyaman dan murah. Di sisi lain, pemberi jasa transportasi konvensional menjadi termarginalkan oleh berbagai keunggulan transportasi online dan menimbulkan konflik diantara kedua pengemudi moda transportasi tersebut.

Izin operasi, warna plat kendaraan, tempat mengambil penumpang, dan tarif adalah aspek-aspek yang menjadi poin utama konflik yang terjadi di antara transportasi konvensional dan transportasi online. UU No. 22/2009 belum mengatur tentang transportasi online. Untuk mengakomodir tuntutan masyarakat, maka pemerintah membuat Permenhub No. 32/2016. Kelemahan peraturan ini karena dianggap pemerintah lebih berpihak kepada salah satu pengusaha angkutan umum (konvensional) tanpa melibatkan pengusaha angkutan umum berbasis aplikasi ketika regulasi ini dibuat. Ini membuat pemerintah merevisinya hingga dua kali dalam dua tahun terakhir, yakni dengan munculnya Permenhub No. 26/2017 yang juga memiliki kelemahan karena dianggap membatasi kuota transportasi online. Terakhir, muncul Permenhub No. 108/2017 sebagai revisi dari Permenhub sebelumnya. Namun Permenhub No.108/2017 tersebut juga tidak mengatur masalah izin operasional bagi ojek online karena tidak termasuk sebagai angkutan orang di dalam UU No. 22/2009. Akibatnya, hingga kini ojek online masih dianggap transportasi ilegal. Plat transportasi online selama ini menggunakan plat prinadi (hitam), bukan angkutan umum (kuning), sehingga pajak yang dibayarkan juga masuk dalam kategori pajak kendaraan pribadi yang relatif lebih murah dibandingkan dengan pajak angkutan umum. Pengambilan penumpang secara non-online yang dilakukan oleh pengemudi transportasi online dianggap melintasi ranah transportasi konvensional. Tarif transportasi online yang relatif kompetitif membuat moda transportasi ini dianggap memonopoli tarif transportasi. Tarif telah menjadi salah satu keunggulan sekaligus sumber konflik dari transportasi online.

Preferensi masyarakat untuk memilih moda transportasi online ketimbang konvensional juga merupakan 'sentilan' terhadap pemerintah yang selama ini dinilai kurang memerhatikan kelayakan, kenyamanan, keamanan transportasi 
yang digunakan masyarakat, dan tarif yang ekonomis. Masih belum komprehensifnya aturan yang ada harus segera diantisipasi oleh pemerintah untuk menghindari konflik yang potensil terjadi di masa yang mendatang.

Daftar Pustaka

Adinda, Samon S. (2015). Teori Konflik dalam Perspektif Sosioligis. https://www.kompasiana.com/samonsari/teori-konflik-dalam-perspektifsosiologis_559367b0a2afbd550704dce6, diakses 5 Desember 2017.

Asuransi Marine. 2017. Asuransi Mobil Untuk GrabCar. http://www.asuransimarine.net/asuransi-mobil-untuk-grab-car/, diakses tanggal 7 Agustus 2017.

Avinda, Sevilla P. (2016). Analisis dampak ojek online terhadap pangkalan ojek konvensional

Griya Pasteur.https://sevindanda.wordpress.com/2016/01/21/analisisdampak-ojek-online-terhadap-pangkalan-ojek-konvensional-griyapasteur/, diakses 10 Agustus 2017.

Ayuwuragil, Kustin. (2017). Tiga Poin Baru di Rumusan Aturan Transportasi Online, https:/ / www.cnnindonesia.com/teknologi/20171020081442-384249668/tiga-poin-baru-di-rumusan-aturan-transportasi-online/, diakses 1 November 2017.

Dephub. (2009). Undang-undang Lalu Lintas No.22 tahun 2009. http://jdih.dephub.go.id/assets/uudocs/uu/uu_no.22_tahun_2009.pdf, diakses 7 Agustus 2017

Dephub. (2016). Peraturan Pemerintah No. 32 Tahun 2016 Tentang Payung Hukum Taksi Aplikasi Yang Transparan. http://www.dephub.go.id/welcome/readPost/permenhub-32-tahun2016-payung-hukum-taxi-aplikasi-yang-transparan, diakses 5 Oktober 2017.

Dephub. 92017a.) Peraturan Menteri Perhubungan Republik Indonesia Nomor PM 26 Tahun 2017 tentang penyelenggaraan angkutan orang dengan kendaraan bermotor umum tidak dalam trayek. http://jdih.dephub.go.id/assets/uudocs/permen/2017/PM_26_Tahun_2 017.pdf, diakses 1 November 2017.

Dephub. (2017b). Mengenal Dan Memahami PM 108 Tahun 2017. http://dephub.go.id/post/read/mengenal-dan-memahami-pm-108tahun-2017, diakses 3 Desember 2017.

Dewanto, Aditya F. (2016). Pengaruh Ojek Online Terhadap Transportasi Masyarakat DKI Jakarta. http://adityafajard.blogspot.co.id/2016/04/penelitian-ilmiah-pengaruhojek-online.html, diakses 10 Agustus 2017.

Go-Jek Indonesia. (2017). Satu Aplikasi Untuk Semua Kebutuhan Anda. https://www.go-jek.com/, diakses tanggal 30 Oktober 2017. 
Grab. (2017). Yang Harus Kamu Tahu Sebelum Melakukan Perjalanan Dengan Grab, https://www.grab.com/id/, diakses tanggal 30 Oktober 2017.

Halomoney. (2017). Promo GoJek Grab Uber Terbaru di November 2017.

https://www.halomoney.co.id/blog/promo-gojek-grab-uber, diakses tanggal 3 Desember 2017.

HeadlineNews Metro TV. (2017). Ratusan Sopir Angkot Gelar Razia TAKSI online, http://video.metrotvnews.com/play/2017/09/28/765211/ratusan-sopirangkot-gelar-razia-taksi-online-di-makassar, diakses tanggal 10 Oktober 2017.

Hidayat, Avid. (2016). Didemo, Manajemen Grab: Kami Legal dan Bayar Pajak. https:// bisnis.tempo.co/read/756045/didemo-manajemen-grab-kamilegal-dan-bayar-pajak\#mHfIxrTHfpWMSPZX.99, diakses 18 Agustus 2017.

Iswanto, Yuska Apitya A. (2017). Mengurai Konflik Tarif Dasar Transportasi Online dan Konvensional di Bogor. http://www.bogortoday.com/mengurai-konflik-tarif-dasar-transportasi-online-dankonvensional-di-bogor/\#, diakses tanggal 2 Oktober 2017.

Julianto, Riva. (2016). Plat Kuning Vs Plat Hitam, https://www.kompasiana.com/rivajulianto/plat-kuning-vs-plathitam_56f54d904c7a612c0b39688a, diakses tanggal 19 Agustus 2017.

Liputan6. (2017). Naik Transjakarta Lebih Cepat dengan Go-Busway di Aplikasi GoJek. http://tekno.liputan6.com/read/2351120/naik-transjakarta-lebihcepat-dengan-go-busway-di-aplikasi-go-jek, diakses tanggal 3 Desember 2017.

Nirmala, Ronna. (2016). Perang Tarif antara Taksi Konvensional dan Aplikasi. https://beritagar.id/artikel/berita/perang-tarif-antara-taksikonvensional-dan-aplikasi, diakses 1 November 2017.

Pranata, Andi Aan. (2017). Organda Makassar Puas dengan Revisi Permenhub Taksi Online.

http://news.metrotvnews.com/read/2017/10/20/776080/organdamakassar-puas-dengan-revisi-permenhub-taksi-online, diakses 13 Agustus 2017.

Purnama, Rayhand. (2017). Masih Revisi UU Ojek Online Tetap Dikuasai Pemda. https://www.cnnindonesia.com/teknologi/20170908172701-384240457/masih-revisi-uu-regulasi-ojek-online-tetap-dikuasai-pemda/, diakses 30 November 2017.

Roen, Ferry. (2011). Ralf Dahrendorf: Teori Konflik. http://perilakuorganisasi.com/ralf-dahrendorf-teori-konflik.html, diakses 7 September 2017.

Ronalyw. (2015). Pemkot tak akui Go-Jek. 
http://beritakotamakassar.fajar.co.id/berita/2015/08/15/pemkot-takakui-gojek/, diakses 12 Desember 2017.

Soekanto, Soerjono. (2009). Peranan Sosiologi Suatu Pengantar. Jakarta: Rajawali Press.

Tribunnews. (2017). Survei YLKI Ungkap Alasan Orang Pilih Transportasi Online. http://www.tribunnews.com/techno/2017/05/12/survei-ylki-ungkapalasan-orang-pilih-transportasi-online, diakses 10 Agustus 2017.

USU. (2016). Jasa Transportasi Berbasis Aplikasi Online.

http://repository.usu.ac.id/bitstream/handle/123456789/65155/Chapter \%20II.pdf?sequence=3\&isAllowed=y , diakses tanggal 21 Agustus 2017 .

Wulandari, Widya. (2016). Analisis Efektivitas Transportasi Ojek Online Sebagai Pilihan Moda Transportasi Di Jakarta (Studi Kasus: Go-Jek Indonesia).

http://digilib.esaunggul.ac.id/analisis-efektivitas-transportasi-ojekonline-sebagai-pilihan-moda-transportasi-di-jakarta-studi-kasus-gojekindonesia-7220.html, diakses tanggal 10 Agustus 2017. 